Proceedings of the 2nd international conference Economic and Business Trends Shaping the Future | 2021

\title{
SHADOW ECONOMY AND CORRUPTION IN THE BALKANS - IS THERE A CONNECTION AND WHAT SHOULD BE DONE ${ }^{1}$
}

\author{
Radostina Ivcheva \\ Faculty of Economics and Business Administration at Sofia University "St. Kliment Ohridski" \\ radi_ivcheva@abv.bg
}

\begin{abstract}
Economies in the Balkans are lagging behind more advanced countries in Europe in their economic development. In some sense that could be a result of the high share of the shadow economy in those countries. Research points out several causes of shadow activities such as low tax morale, high levels of unemployment, weak business environment and very high poverty levels, lack of trust in the state and the public institutions, high perceptions of corruption and also the high taxation levels. This issue affects directly the economy as well as indirectly the whole society. This paper aims to find a positive link between the volumes of the shadow economy and corruption in eight Balkan economies: Slovenia, Croatia, Bosnia and Herzegovina, Serbia, Montenegro, Kosovo and North Macedonia and Bulgaria.
\end{abstract}

Keywords: shadow economy, corruption, socio economic issues

JEL classification: D73, E26, O17

\section{INTRODUCTION}

Shadow economy shrunk across much of Europe since the global financial crisis, but still remains a significant share of GDP, especially in the Balkans. Shadow economy is on average, around 1520 percent of GDP in advanced economies and around 30-35 percent of GDP in emerging economies (Medina and Schneider 2018).

There is no single definition of shadow economy. One of the main authors in this field Friedrich Schneider explains this phenomenon as "all market-based legal production of goods and services that are deliberately concealed from public authorities for the following: to avoid paying income, value-added, or other taxes; to avoid paying social security contributions; to avoid having to meet certain legal labor market standards such as minimum wages; to avoid complying with certain administrative procedures". This is the definition which is recognized id this paper as well.

On the other hand corruption is a complex phenomenon, which roots lie in bureaucratic and political institutions, and its effect on development varies with country conditions. Corruption has a disproportionate impact on the poor and most vulnerable, increasing costs and reducing access to services, including health, education and justice.

The main hypothesis of this paper is that there is a positive relation between corruption and the size of shadow economy in the Balkans. This can have a strong impact not only on the economic development on the countries in the region but on their future in the European Union as well.

\section{EXPLAINING THE MAIN CONCEPTS}

\footnotetext{
${ }^{1}$ This research paper is financed by the "Scientific Research " Fund under project № 80-10-192/06.04.2021.

http://hdl.handle.net/20.500.12188/15918

http://doi.org/10.47063/EBTSF.2021.0005
} 
There are many theories about the existence, causes and effects of the shadow economy. The classical/Marxian approach argues that in the center of the informal economy is the "surplus" labor force which is a product the process by which the capitalist economy secures its resources minus the people who traditionally survived on those resources. On the other hand according to the dualistic/modernization theory, shadow economy consists of marginal activities - distinct from and not related to the formal sector - that provide income for the poor and a safety net in times of crisis. In the neoliberal/legalist theory, the informal sector is comprised of micro - entrepreneurs who choose to operate informally in order to avoid the costs, time and effort of formal registration. Significant element of this theory is the delay of growth due to lower level of productivity, limited investments, inadequate and inefficient tax system, low level of implementation of technological progress and complications in macroeconomic policy (Koufopoulou et al. 2019). However Loayza and Rigolini (2006) and Medina et al. (2017) came to the conclusion that in some cases the shadow economy can serve as a source of employment and income in the absence of opportunities in the formal sector, or as a safety net during cyclical downturns. In other words in some cases the shadow economy can contribute to overall growth (Schneider 2004).

Although shadow economy can act as a source of supplemental income, its existence creates inefficiencies in the broader economy. The costs associated with shadow economy include distortions in the labor market, forgone revenue due to underreporting of wages and output, suboptimal provision of public goods, and lower provision of and access to financing. Limited scale of production also tends to impede firms' productivity and innovation (Kelmanson et all. 2019).

Shadow economy decreases tax revenue, with consequences on government's ability to provide public services and hence increasing the nation's debt. Shadow economy includes economic activities and respective incomes that are not under the government regulation and taxation. Feige and Cebula (2012) come to the conclusion that noncompliance shifts real resources from honest taxpayers to dishonest evaders and tax liabilities from present to future generations. In this sense, there is a shift from legal and regulated economy to the shadow economy.

Martha Chen (2007) identified the existence of three approaches in the relation between official and shadow economies: dualism, structuralism and legalism. Dualism establishes that shadow economy has few connections to official economy and operates separately. Its hypothesis sustain that regulation had segmented the market, as a derivation from the rigidities of official economy. These few connections happen since both economies share some common factors, like unemployment, corruption level or monetary mass, allowing the transference of resources between these economies.

On the other hand, structuralism assumes that official and shadow economies are intrinsically connected. This means that some agents from the official economy encourage relations with shadow economy in order to decrease input costs. Agents meet their interests and consequently the shadow economy is used to expand the official economy. Legalism establishes a relation between the shadow economy and the regulatory environment of the official economy, outside the scope of the agents' actions. There is a collusion of interests between economic agents and government in the regulated official economy.

Schneider et al. (2008) presented another perspective. They suggest that to understand the consequences of shadow economy we should focus on the nature of the relation with formal economy. For these authors, what is important is to know whether, in the relations between both economies, substitute effects such the passage of productive activities overcome complementary ones, like economic growth. When both economies complement instead of competing each other, the shadow economy stimulates the growth of official economy. The authors justified this claim 
with the value added in the shadow economy, which is subsequently transferred to the official economy. However, if the competition between both economies prevails, unfair competition affects negatively the allocation of resources. So their research has shown us, that there are positive and negative impacts of shadow economy in official economy.

Underground economic activity is, by definition, not directly observable or reported. However, it may be assumed that shadow activities depend positively on the opportunity costs of remaining formal and negatively on the probability of detection and potential fines. The literature suggests some potentially observable causes of the underground economy. Changes in certain tax rates are thought to be one cause because they alter people's incentives to evade paying taxes. Changes in people's opportunities to evade taxes is another cause. Such changes may be reflected in changes in the sectors where people are employed (e.g. the growth of sectors where evasion is easier) the type of employment (e.g. shifts from paid to self-employment) or market structures (e.g. the supplanting of small shops by large stores) (Almenar et all. 2019). Changes may also occur in people's attitudes towards the morality of cheating on their taxes. Frey and Weck-Hanneman (1984) argued that the causal variables in MIMIC models are in fact determinants of hidden economic output and that it is reasonable to interpret their combined effect as a measure of the underground economy.

There is considerable theoretical and empirical agreement on the factors that determine the relative size of the underground economy. These factors include the tax burden, regulations, enforcement, labor force characteristics etc. Growth in the underground economy may also reflect citizens' dissatisfaction with public services received in exchange for taxes and hence with tax rates (Hill, 2002). Evasion of tax payments, in turn, lessens the government's ability to finance public goods and services. There are also various possible indirect indicators of changes in the level of underground activity. Some studies have focused on monetary factors such as changes in cash holdings that can be linked statistically to changes in tax rates as indicators of changes in the underground economy.

Given that there are significant costs associated with shadow economies, policy makers seek to understand the drivers and possible solutions. Identifying the causes and reducing the size of the shadow economy entails several challenges. For instance, tax morale, enforcement, rates, and compliance all interact with each other, as well as the provision of public services and government effectiveness. Finally, once drivers are identified, policies must be calibrated so that economic activity is formalized without stifling entrepreneurship or cutting off incentives to work (Schneider 2013).

Theoretically, corruption and the shadow economy can either be complements or substitutes (Dreher and Schneider 2006). Choi and Thum (2005) present a model where the option of entrepreneurs to go underground constrains a corrupt official's ability to ask for bribes. Dreher et al. (2008) extend the model to the explicit specification of institutional quality. The model shows that corruption and the shadow economy are substitutes in the sense that the existence of the shadow economy reduces the propensity of officials to demand non declared payments.

To the contrary Johnson et al. (1997) establish a model corruption and the shadow economy as complements. In their full-employment model, labor can either be employed in the official sector or in the underground economy. Consequently, an increase in the shadow economy always decreases the size of the official market. In their model, corruption increases the shadow economy, as corruption can be viewed as one particular form of taxation and regulation. According to Hibbs and Piculescu (2005), corrupt bureaucrats can overlook unofficial production in exchange for a bribe, so that corruption increases the size of the underground sector. 
Similar studies related to Balkan countries are limited in number. Hysa (2011), in her study on the Balkans for the period 2002-2010, argues that the negative relation between corruption and human development is strong in Serbia, Montenegro, Albania, and Former Yugoslav Republic of Macedonia, weak in Croatia, and insignificant in the case of Bosnia and Herzegovina.

\section{DATA, METHODOLOGY AND FINDINGS}

This paper examines the relation between the size of the shadow economy in eight Balkans countries: Slovenia, Croatia, Bosnia and Herzegovina, Serbia, Montenegro, Kosovo and North Macedonia and Bulgaria, and the estimations of the Corruption Perception index for a period of twenty years between 1995-2015 where we see approximately two full economic cycles. To do that we perform a OLS regression with one dependent variable being the shadow economy and two explanatory variables - corruption and capital per capita.

Data for the shadow economy are taken from an IFM Working paper prepared by Leandro Medina and Friedrich Schneider (2018). The authors estimate the size and development of the shadow economy of 158 countries over the period 1991-2015 using the MIMIC approach.

To estimate corruption, we employ Corruption Perceptions Index. The Corruption Perceptions Index ${ }^{2}$ (CPI) is an index published annually by Berlin-based Transparency International since 1995 which ranks countries "by their perceived levels of public sector corruption, as determined by expert assessments and opinion surveys." The CPI generally defines corruption as an "abuse of entrusted power for private gain". Corruption generally comprises illegal activities, which are deliberately hidden and only come to light through scandals, investigations or prosecutions. The sources and surveys which make up the CPI, ask their respondents questions which are based on carefully designed and calibrated questionnaires. The CPI contains informed views of relevant stakeholders, which generally correlate highly with objective indicators, such as citizen experiences with bribery as captured by the Global Corruption Barometer. For a country/territory to be included in the ranking, it must be included in a minimum of three of the CPI's data sources. If a country is not featured in the ranking, then this is solely because of insufficient survey information and not an indication that corruption does not exist in the country.

Figures for the capital per capita are calculated using data about the capital stock for each country taken from "IMF Investment and Capital Stock Dataset, 2017" and data for the population taken form the World Bank dataset.

Theoretically there is not a single understanding about the relation between corruption and the shadow economy. But on the other hand there are reason to believe that the relation might differ among high and low income countries. In high income countries, the official sector provides public goods like the rule of law, enforcement of contracts, and police protection. Usually, only craftsmen or very small firms take the option of going underground. In this case, the shadow economy is only hidden from tax inspectors and other officials. Typically high income countries typically show small levels of corruption. Moreover, in those countries corruption quite often takes place to bribe officials to get big contracts from the public sector (e.g., in the construction sector), which are then handled in the official economy and not in the shadow economy. Hence, corruption in high income countries can be a means of achieving certain benefits which make work in the official economy easier, e.g., winning a contract from a public authority, getting a license (e.g., for operating taxes, providing other services, or getting permission to convert land into "construction ready" land). In

\footnotetext{
${ }^{2}$ https://www.transparency.org/en/cpi/2020/index/nzl
} 
high income countries people thus bribe in order to be able to engage in more official economic activities (Dreher and Schneider, 2006).

To the contrary in low income countries as those in the Balkans different mechanisms to prevail. Instead of working partly in the official sector and offering additional services underground as in high income countries, enterprises completely engage in underground activity. Examples of enterprises that sometimes operate completely underground are restaurants, bars, or hairdressers. As one reason for this, the public goods provided by the official sector are in many developing countries less efficient as compared to high income countries.

The hypothesis of this paper is that there is a positive relation between corruption and the size of the shadow economy in countries in Balkans. In order to verify the hypothesis we first create a skater plot using data for the size of shadow economy and the Corruption perception index in all examined countries.

Figure 1. Relation between the size of shadow economy and corruption in the Balkans (1995-2015)

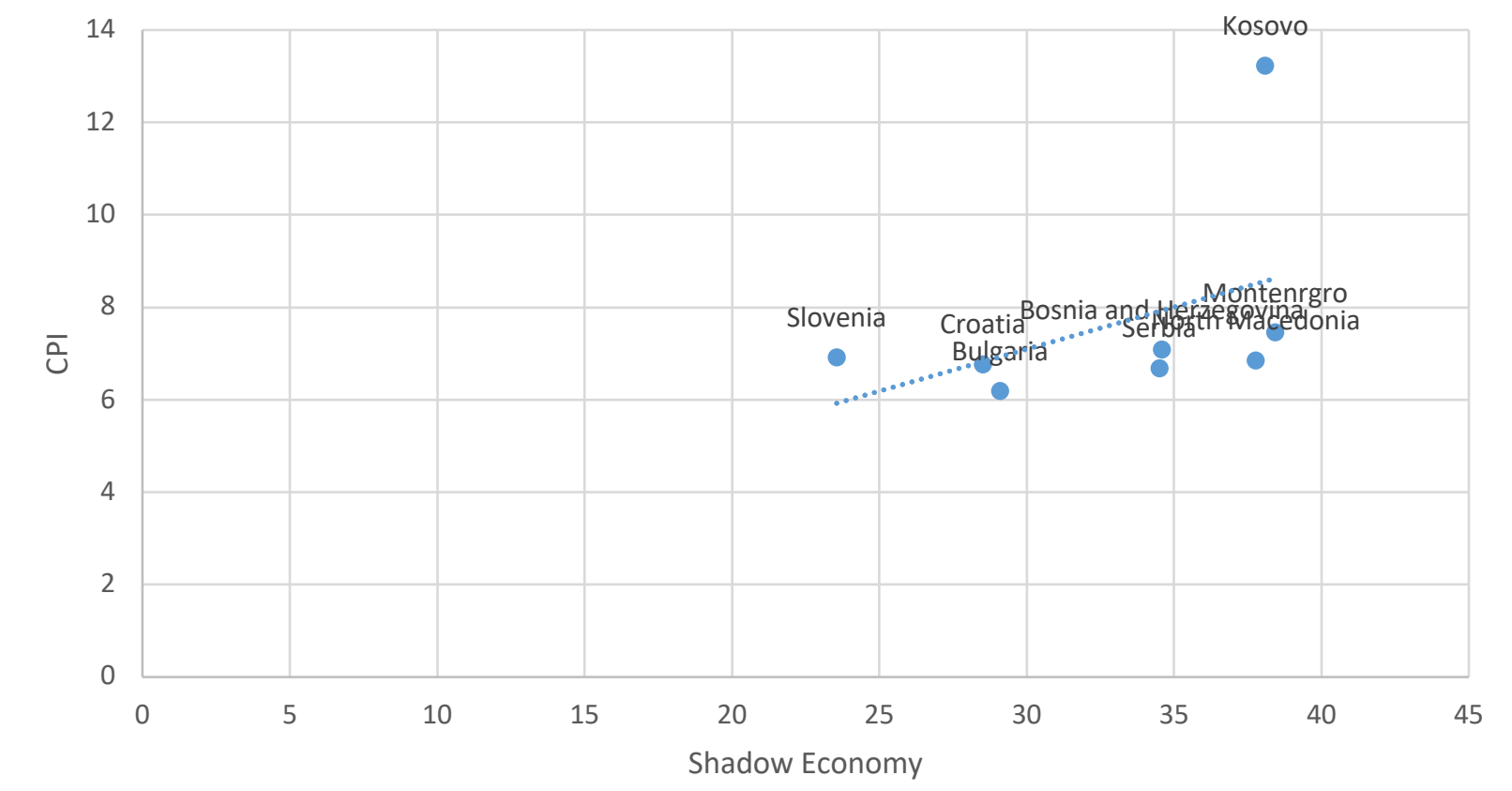

Figure 1 shows a positive relation between the size of shadow economy and corruption for the examined countries in the period. In order to find a stronger prove for the hypothesis the correlation coefficient between the size of the shadow economy and corruption for all countries for the period 1995-2015 is calculated. ${ }^{3}$ The calculations show us a correlation of approximately 0.5 which falls into the category for moderate relation. That proves that our hypothesis is right.

To further confirm out findings a multiple OLS regression including one dependent variable and two explanatory variables is performed. Our dependent variable is the size of shadow economy measured as present of GDP for each country. The explanatory variables are corruption and capital per capita in the Balkan countries. All data are averages over the period 1995-2015.

\footnotetext{
${ }^{3}$ The absolute value of the correlation coefficients is in the range from 0 to 1 . If the correlation coefficient is a positive number, the dependence is positive, ascending - the larger values of one variable correspond to larger values of the other variable. If the correlation coefficient is a negative number, the dependence is negative, descending - higher values of one variable correspond to lower values of the other variable.
} 
F-test on the significance of the explanatory variables show that they are good predictors of the degree of shadow economy. This is in line with our hypothesis. Moreover the results for the t-stats and p-values help us to reject the null hypothesis that there is no relation between the variables. Finally we look at the R-squared values. The R-squared value of $\sim 0.821$ indicates that our model accounts for about $82.1 \%$ of the dependent variable's variance. The regression results are shown in Table 1.

Table 1. Regression results

\begin{tabular}{|c|c|c|c|c|c|}
\hline Table 1 & & & & & \\
\hline Regressio & Statistics & & & & \\
\hline Multiple R & 0,90583296 & & & & \\
\hline R Square & 0,820533351 & & & & \\
\hline Adjusted R & & & & & \\
\hline Square & 0,748746692 & & & & \\
\hline Standard Error & 2,852293494 & & & & \\
\hline Observations & 8 & & & & \\
\hline & $d f$ & $S S$ & $M S$ & $F$ & Significance F \\
\hline Regression & 2 & 185,9819992 & 92,991 & 11,43016 & 0,013644555 \\
\hline Residual & 5 & 40,67789088 & 8,135578 & & \\
\hline Total & 7 & 226,6598901 & & & \\
\hline & Coefficients & $\begin{array}{c}\text { Standard } \\
\text { Error }\end{array}$ & $t$ Stat & P-value & \\
\hline Intercept & 26,37556952 & 5,5768445 & 4,729479 & 0,005199 & \\
\hline CPI & 0,829559055 & 0,331774642 & 2,500369 & 0,054466 & \\
\hline $\begin{array}{l}\text { Capita per } \\
\text { capita }\end{array}$ & $0,274473225^{-}$ & 0,068272443 & $-4,02026$ & 0,010118 & \\
\hline
\end{tabular}

(Source: Author's calculations)

Having in mind that the business environment and reduction of the hidden economy is a critical dimension of the Copenhagen economic criteria ${ }^{4}$ for EU membership countries in the Balkans that are in the process of negotiations have to increase their effort to lower the corruption and shadow economy within them. The improvement of the institutional environment, quality of public services and lower tax burden are expected to be more effective than repression measures in the combat against the shadow economy. And as we can see in the last European Commission report "Progress towards Meeting the Economic Criteria for EU Accession"s all of the countries in the region have made some progress in that direction but still have some way to go. On the other hand the share of shadow economy in the Balkan countries that are already a member of the European Union has been shrinking in the years after their accession to the single market.

4 https://ec.europa.eu/info/business-economy-euro/economic-and-fiscal-policy-coordination/international-economicrelations/enlargement-and-neighbouring-countries/enlargement/economic-accession-criteria_en

5 https://ec.europa.eu/info/publications/progress-towards-meeting-economic-criteria-eu-accession-eu-commissions2019-assessments_en 
Friedrich Schneider (2017) came out with a different point of view about the fight with shadow economy. He studies the relation of cash and volume of shadow economy in 38 European countries. His results clearly show that the share of cash payments has an influence on the size and development of the shadow economy and is statistically significant, or in other words the more cash, the larger the shadow economy and vice versa. Having that in mind Schneider estimates that reduction in cash or introduction of a cash limit will lead to a reduction in the volume of shadow economy between 2 and 20\% (in the case of abolishing cash). But on the other hand he says that there are weak empirical evidence that limitation or abolishment of cash and more comprehensive state control over individuals' financial flows and funds will effectively fight shadow economy. Instead of abolishing cash all together a paper "Shining Light on the Shadow Economy: Opportunities and Treats" created by Organization for Economic Co-operation and Development (2017) suggests that shadow economy can be reduced by whole of government approaches, also known as joined-up government that are intended to overcome boundary problems between different parts of government to allow citizens easier access to services, avoid duplication and increase efficiency. The report also states that international co-operation is highly important to tackling cross-border shadow economy activity. This includes sharing of information, intelligence and co-operation on live cases. Information sharing is made possible through bilateral treaties, tax information exchange agreements or the Multilateral Convention on Mutual Administrative Assistance in Tax Matters. Another way governments can deal with shadow economy is by reinforcing social norms working through customers and others to help reduce opportunities for noncompliant behavior, in particular by not facilitating shadow economy behavior.

\section{CONCLUSION}

This paper was started with the hypothesis that corruption and shadow economy in the Balkans have a strong positive relation. That can be harmful to the countries that are in the process of negotiations for becoming members of the European Union and for those that are members already for it can lead to lower international image.

The empirical findings were in line with the expectations so we can say that there is a positive relation between the two variables for the given period. In that sense corruption and shadow economy are problems that the countries in the Balkans have to work on solving. All countries in the region have the resources needed for a developed country and they have high economic margins throughout the years, therefore an improvement of the government performance would be enough to generate a decrease in corruption and speeding up the proses of EU membership.

\section{REFERENCES:}

Achim, M.V., Văidean, V.L., Borlea, S.N. and Florescu, D.R. (2021) "The Impact of the Development of Society on Economic and Financial Crime. Case Study for European Union Member States", Risks, [online] Vol. 9 No. 5, p.97, available at: http://dx.doi.org/10.3390/risks9050097.

Almenar, V., Sánchez, J.L. and Sapena, J. (2019) "Measuring the shadow economy and its drivers: the case of peripheral EMU countries", Economic Research-Ekonomska Istraživanja, Vol. 33 Issue 1, pp. 29042918, available at: https://www.tandfonline.com/doi/full/10.1080/1331677X.2019.1706601 (accessed 25 October 2021).

Cebula, R.J. and Feige, E. (2012) "America's unreported economy: measuring the size, growth and determinants of income tax evasion in the U.S", Crime Law and Social Change, Vol. 57 No. 3, pp. 265285. 
Chen, M.A. (2007) "Rethinking the Informal Economy: Linkages with the Formal Economy and the Formal Regulatory Environment", working paper [46], United Nations, Department of Economics and Social Affairs.

Choi, J.P. and Thum, M. (2005), "Corruption and the shadow economy", International Economic Review, Vol. 46 No. 3, pp. 817-836.

Dreher, A., Kotsogiannis, C. and McCorriston, S. (2009) "How Do Institutions Affect Corruption and the Shadow Economy", Discussion Papers from University of Exeter, Department of Economics, No. 505.

Dreher, A. and Schneider, F. (2009) "Corruption and the shadow economy: an empirical analysis", Public Choice, Vol. 144 No. 1, pp. 215-238.

Frey, B.S. and Weck-Hanneman, H. (1984) "The hidden economy as an 'unobserved' variable", European Economic Review, Vol. 26, Issue 1-2, pp. 33-53.

Feruni, N., Hysa, E., Panait, M., Rădulescu, I.G. and Brezoi, A. (2017) "The Impact of Corruption, Economic Freedom and Urbanization on Economic Development: Western Balkans versus EU-27", Sustainability, Vol. 12, Issue 22, available at: https://www.mdpi.com/2071-1050/12/22/9743/htm (accessed 25 October 2021).

Hibbs Jr., D.A. and Piculescu, V. (2005) "Institutions, corruption and tax evasion in the unofficial economy", Göteborg, Department of Economics.

Hill, R. (2002) "The underground economy in Canada: Boom or bust", Canadian Tax Journal, Vol. 50 No. 5, pp.1641-1654.

Hysa, E. (2009) "Corruption and Human Development Correlation in Western Balkan Countries", Euro Economica, Vol. 30 No. 4, pp. 147-157.

Johnson, S., Kaufmann, D. Shleifer, A., Goldman, M. I., and Weitzman, M. L. (1997) "The unofficial economy in transition", Brookings Papers on Economic Activity, Vol. 2, 159-221.

Kadia, A. (2020) "Corruption and Economic Growth in the Balkan Countries", European Journal of Economics and Business Studies, European Center for Science Education and Research, Vol. 3 No. 3, pp. $88-97$

Kelmanson, B. Kirabaeva, K., Medina, L. Mircheva, B. and Weiss, J. (2019) "Explaining the shadow economy in Europe: size, causes and policy options", Working Paper, IMF, Washington DC, 13 December. Koufopoulou, P., Williams, C.C., Vozikis, A. and Souliotis, K. (2019) "Shadow Economy: Definitions, terms \& theoretical considerations", Advances in Management and Applied Economics, Vol. 9, Issue 5, pp. $35-57$

Loayza, N.V. and Rigolini, J. (2006) "Informality Trends and Cycles", Policy Research Working Paper No. 4078. World Bank, Washington DC.

Magessi, N.T. and Antunes, L. (2015), "Shadow economy and wealth distribution", Advances in Artificial Economics, Vol. 127, pp 169-179.

Medina, L. and Schneider, F. (2018) "Shadow Economies Around the World: What Did We Learn Over the Last 20 Years?”, IMF Working Paper, Washington DC, 24 January.

Nikopur, H., Shah Habibullah, M. and Schneider, F. (2009) “The shadow economy Kuznets's curve panel data analysis", MPRA Paper No. 12956, pp.169-179.

Schneider, F. (2017), "Restricting or Abolishing Cash: An Effective Instrument for Fighting the Shadow Economy, Crime and Terrorism?", International Cash Conference 2017 - War on Cash: Is there a Future for Cash? 25 - 27 April 2017, Island of Mainau, Germany.

Organization for Economic Co-operation and Development, (2017), Shining Light on the Shadow Economy: Opportunities and Treats, available at: https://www.oecd.org/tax/crime/shining-light-on-the-shadoweconomy-opportunities-and-threats.pdf (accessed 25 October 2021).

United Nations Office on Drugs and Crime Vienna, (2013) Business, Corruption and Crime in The Western Balkans: The impact of bribery and other crime on private enterprise, available at: https://www.unodc.org/documents/data-and-analysis/statistics/corruption/Western balkans business corruption_web.pdf (accessed 25 October 2021) 